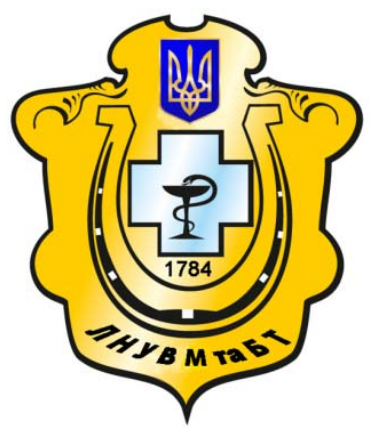

Науковий вісник Львівського національного університету ветеринарної медицини та біотехнологій імені С.З. Гжицького

Scientific Messenger of Lviv National University of Veterinary Medicine and Biotechnologies named after S.Z. Gzhytskyj

doi:10.15421/nvlvet7620

ISSN 2519-2701 print

ISSN 2518-1327 online

$\underline{\text { http://nvlvet.com.ua/ }}$

УДК 332:334:338:339:658

\title{
Аспекти розвитку різних організаційно-правових форм підприсмницької діяльності в аграрному секторі
}

\author{
І.Б. Смолинець \\ smolinecz86@mail.ru
}

Львівський національний університет ветеринарної медицини та біотехнологій імені С.3. Гжиџького, вул. Пекарська, 50, м. Львів, 79010, Украӥна

Одним з найважливіших напрямів в иъвому контексті є проблеми організаційно-правових форм розвитку підприємнииької діяльності в сільському господарстві. В умовах конкурентного ринкового середовища важливе значення для забезпечення стабільного й ефективного аграрного виробниитва мають механізми регулювання процесів відтворення 6 АПК, серед яких чільне місие належить формам підприємниџької діяльності. У сучасних економічних умовах важливим фактором підвищення ефективності розвитку продовольчого підкомплексу є удосконалення даних форм. Проте слід визнати, що нині форми підприємницької діяльності перебувають в стані формування та розвитку. Тому проблеми реформування аграрного сектора економіки постійно перебували і перебувають у полі зору економічної науки. В історичному аспекті розвитку підприємницька діяльність налічує такі форми: приватні підсобні господарства, одноосібні володіння, господарства населення, селянські фермерські господарства, приватні та державні сільськогосподарські підприємства, колективні господарства, зокрема селянські спілки, агрофірми, міжгосподарські підприємства і об'єднання, різного роду та видів товариства, які поділяються за формою об'єднання та рівнем відповідальності. Найважливіші з них, які прижились та функиіонують в сільському господарстві, є сільськогосподарські підприсмства, зокрема приватні, та господарства населення. Ефективному розвитку підприсмницької діяльності в сільському господарстві перешкоджають слабка адаптація до ринкових умов та низька інвестииійна привабливість аграрного виробництва і господарських формувань, безсистемність і розпороченість надходжень коштів у модернізаиію виробничої діяльності, недостатня державна підтримка, недосконалість організачійно-економічного механізму управління розвитком різних організаційно-правових форм підприємнииької діяльності в аграрному секторі.

Ключові слова: сільське господарство, підприємницька діяльність, аграрне виробниџтво, ринок, аспекти розвитку організаиійно-правових форм підприємницької діяльності.

\section{Аспекты развития различных организационно-правовых форм предпринимательской деятельности в аграрном секторе}

\author{
И.Б. Смолинец \\ smolinecz86@mail.ru
}

\begin{abstract}
Львовский национальный университет ветеринарной медицины и биотехнологий имени С.3. Гжицкого, ул. Пекарская, 50, г. Львов, 79010, Украина
\end{abstract}

Одним из важнейших направлений в этом контексте проблемы организационно-правовых форм развития предпринимательской деятельности в сельском хозяйстве. В условиях конкурентной рыночной среды важное значение для обеспечения стабильного и эффективного аграрного производства имеют механизмы регулирования процессов воспроизводства в АПК, среди которых главное место принадлежит формам предпринимательской деятельности. В современных экономических условиях важным фактором повышения эффективности развития продовольственного подкомплекса является совершенствование данных форм. Однако следует признать, что в настоящее время формы предпринимательской дея-

Citation:

Smolynets, I.B. (2017). Different aspects of organizational-legal forms of business in agricultural sector. Scientific Messenger LNUVMBT named after S.Z. Gzhytskyj, 19(76), 100-107. 
тельности находятся в состоянии формирования и развития. Поэтому проблемы реформирования аграрного сектора экономики постоянно находились и находятся в поле зрения экономической науки. В историческом аспекте развития предпринимательская деятельность насчитывает следуюшие формы: частные подсобные хозяйства, единоличные владения, хозяйства населения, крестьянские фермерские хозяйства, частные и государственные сельскохозяйственные предприятия, коллективные хозяйства, в частности крестьянские союзы, агрофирмы, межхозяйственные предприятия и объединения, разного рода и видов общества, которые делятся по форме объединения и уровню ответственности. Важнейшие из них, которые прижились и функиионируют в сельском хозяйстве, являются сельскохозяйственнье предприятия, в том числе частные, и хозяйства населения. Эффективному развитию предпринимательской деятельности в сельском хозяйстве препятствуют слабая адаптация к рыночным условиям и низкая инвестиционная привлекательность аграрного производства и хозяйственных формирований, бессистемность и разбросанность поступлений средств в модернизацию производственной деятельности, недостаточная государственная поддержка, несовершенство организационноэкономического механизма управления развитием различных организационно-правовых форм предпринимательской деятельности в аграрном секторе.

Ключевые слова: сельское хозяйство, предпринимательская деятельность, аграрное производство, рынок, аспекть развития организационно-правовых форм предпринимательской деятельности.

\title{
Different aspects of organizational-legal forms of business in agricultural sector
}

\author{
I.B. Smolynets \\ smolinecz86@mail.ru \\ Lviv National University of Veterinary Medicine and Biotechnologies named after S.Z. Gzhytskyi, \\ Pekarska Str., 50, Lviv, 79010, Ukraine;
}

\begin{abstract}
One of the most important areas in this context is the problem of organizational-legal forms of entrepreneurship in agriculture. In a competitive market environment essential to ensure stable and efficient agricultural production with mechanisms of regulation of reproduction in agriculture, including prominent place belongs to forms of entrepreneurship. In today's economy an important factor in increasing the efficiency of the food is sub improving data forms. However, it should be recognized that the current form of business activity in a state of formation and development. Therefore, the problems of reforming the agricultural sector, always were and are in the field of economics. The historical aspect of business activities includes the following forms: private farms, individual holdings, farms, peasant farmers, private and public agricultural enterprises, collective farms, including peasant associations, agricultural firms, inter-farm enterprises and associations of various kinds and types companies, which are divided in the form of association and level of responsibility. The most important of them taken root and function in agriculture are agricultural enterprises, including private and public sector. Effective business development in agriculture hamper poor adaptation to market conditions and low investment in agricultural production and business units, unsystematic and dispersed revenues in modernization of production activity, insufficient state support, inadequate organizational and economic mechanism of development of various organizational and legal forms of business activities in the agricultural sector. The agricultural company providing the agricultural sector and its intensive development, because it is characterized by business activities using the latest technology and organization management. As a result of increasing production efficiency, increased employment, new products and services, expanding market. One of the main features of a private business interest.
\end{abstract}

Key words: agriculture, entrepreneurship, agricultural production, market development aspects of legal forms of business activity.

\section{Вступ}

Формування нових організаційно-правових форм підприємницької діяльності в сільському господарстві на кооперативних засадах $з$ використанням основ горизонтальної та вертикальної інтеграції, що обумовить можливість впровадження в аграрне виробництво сучасних технологій та інноваційних проектів, сприятиме зростанню доходів сільськогосподарських виробників за рахунок їхньої участі в подальших сфеpax, що позитивно вплине на підвищення конкурентоспроможності підприємницької діяльності в сільському господарстві та забезпечення аграрного ринку новими якісними та екологічними продуктами.

Аналіз досліджень проблеми. Різні аспекти підприємництва та підприємницької діяльності в сільському господарстві висвітлені в економічній літературі, зокрема в працях зарубіжних авторів - X. Ансоффа, Є. Бем-Баверка, Ф. Візера, П. Друкера, Н. Єрмоленкова, А. Маршала, Дж. Мілля, М. Новакова, С. Сісмонді, Н. Скворцова, Ф. Хаєка, Й. Шумпетера та вітчизняних учених - Ю. Губені, Т. Дудара,
В. Зіновчука, В. Липчука, Ю. Лупенка, О. Мазуренко, М. Маліка, С. Реверчука, П. Саблука, Г. Черевка, Д. Шеленко, М. Шульського, І. Яціва та ін.

Узагальнення результатів проведених досліджень засвідчує, що, незважаючи на значний науковий внесок у розв'язання проблем розвитку підприємницької діяльності в сільському господарстві, чимало аспектів поки що залишаються нез'ясованими. Подальшого вивчення потребує комплекс питань, пов'язаних із дослідженням чинників впливу на розвиток різних організаційноправових форм підприємницької діяльності в сільському господарстві.

Мета статmi. Висвітлити аспекти розвитку різних організаційно-правових форм підприємницької діяльності в аграрному секторі, форми власності на засоби виробництва й способи їі використання, дати характеристику сильних і слабких сторін порівнюваних господарських формувань. Все це в комплексі дозволить визначити найефективніші та найперспективніші з них. Нами використані традиційні методи та підходи економічного аналізу, зроблено посилання на 
власні публікації, де висвітлено окремі аспекти та результати дослідження.

\section{Результати та їх обговорення}

Ефективному розвитку підприємницької діяльності в сільському господарстві перешкоджають слабка адаптація до ринкових умов та низька інвестиційна привабливість аграрного виробництва і господарських формувань, безсистемність і розпорошеність надходжень коштів у модернізацію виробничої діяльності, недостатня державна підтримка, недосконалість організаційноекономічного механізму управління розвитком різних організаційно-правових форм підприємницької діяльності в аграрному секторі.

Умови ринкової економіки змушують різних суб'єктів підприємницької діяльності діяти відповідно до типу організаційно-правових форм, будувати свою стратегію поведінки з урахуванням таких принципів:

- незалежність. Коли суб'єкт підприємницької діяльності в умовах ринкової економіки працює на основі принципу незалежності. Якщо підприємство в сільському господарстві працює в рамках, визначених законодавчою базою, держава не має права втручатися у його діяльність, винятком є лише підприємства сільського господарства державної форми власності;

- ініціативність. Враховуючи змінність смаків та уподобань споживачів на ринку, кожне сільськогосподарське підприємство пропонує на ринок ті товари та послуги, що користуються попитом і принесуть йому прибуток;

- конкуренція між різними суб'єктами підприємницької діяльності в сільському господарстві виступає тим чинником, що спонукає їх до використання та впровадження широкого розмаїття економічних стратегій. Адже конкуренція виступає тим фактором, що стимулює ефективний розвиток сільського господарства як галузі в цілому, так і допомагає визначити неконкурентоспроможних суб'єктів на ринку;

- ризик та відповідальність. Враховуючи специфіку кожної форми підприємницької діяльності в сільському господарстві, варто відзначити різноманітну кількість ризиків, що іiі супроводжують та міру їх впливу. I тому кожен суб'єкт підприємницької діяльності в аграрному виробництві не залежно від організаційно-правової форми повинен працювати в напрямку зменшення ймовірності настання ризиків та їхнього рівня впливу і діяти в рамках чинного законодавства.

Сучасні умови ведення бізнесу в сільському господарстві сприяють не лише позитивним тенденціям щодо насичення ринку України продуктами харчування рослинного і тваринного походження, а й забезпечують створення потужної бази для робочої сили, особливо у приватних підсобних господарствах, яким властиві ознаки господарств населення. Розкриваючи сутність поняття приватне підсобне підприємство, враховуючи його правовий статус та соціальноекономічну роль, варто визначити, що це господарство, в розпорядженні якого наявне рухоме і нерухоме майно, що має вартісну оцінку та використовується для задоволення різносторонніх потреб власника як матеріальних, так і побутових. Така одиниця господарювання є структурною складовою аграрного виробництва продукції тваринного та рослинного походження (Yanchuk, 2000).

Належна роль у структуризації агарного виробництва, зокрема сільського господарства, належить одноосібним володінням. Основою одноосібного володіння $є$ приватна власність громадян України, що працюють на ринку, як суб'єкти підприємницької діяльності - юридичні особи. Одноосібна власність зосереджена у межах однієї сім’ї або однієї особи. Варто відзначити, що на ринку, крім одноосібного володіння, існує така форма підприємницької діяльності, як спільне підприємство - це юридична особа, що заснована на засадах приватної власності членів однієї сім’ї або спільної власності окремої сім’ї та фізичної особи, що зареєстрована як суб'єкт підприємницької діяльності.

Дослідженнями доведено, що найбільша частка у структурі виробництва валової продукції сільського господарства належить господарствам населення, які в сучасних ринкових умовах працюють 3 метою об'єднання та реалізації особистих та суспільних інтересів. Такі суб'єкти підприємницької діяльності виступають потужним індикатором конкурентної боротьби у сільському господарстві, враховуючи рівень використання трудових ресурсів, забезпечення матеріальних ресурсів, системи реалізації виробленої продукції.

Історичні процеси, які супроводжувались зміною суспільно-політичних формацій, знаходили свій відбиток в тенденціях розвитку підприємництва в сільському господарстві i, як пише професор М.Г. Шульський, «...до влади приходили різні політичні сили, які суттєво, а інколи й докорінно впливали і впливають не тільки на організаційні форми ведення сільськогосподарського виробництва, а взагалі на все суспільне виробництво, проте особисте господарство населення, як форма ведення виробництва продукції на землі, зберігалося і зберігається. Правда, інколи змінювалися їх розміри, назви, системи взаємовідносин, однак суть їх залишалася для сільського трудівника незмінною - забезпечення його засобами існування» (Shulskyi, 2003).

Поряд 3 цим слід відзначити, що постійний розвиток даної форми підприємницької діяльності, що функціонувала в різних регіонах України, змінюючи лише одну назву на іншу: особисті, підсобні, присадибні, індивідуальні господарства населення. У наукових дослідженнях Костецької Я. зазначено, що на території Галичини в 1902 році функціонувало 42,3\% селянських господарств, у власності яких було менше 2 га землі, наприкінці 19 століття на території Закарпаття і Буковини налічувалось 50\% господарств даної категорії, а за часів правління Російській імперії 19\% селянських дворів мали менше ніж 3,3 га (Kostetska, 1996). Невеликі за обсягом селянські господарства функціонували в Україні за різних політичних устроїв, хоча і відрізнялись системою організації економіч- 
них взаємовідносин, технічними засобами, розмірами землі, кількістю тварин та рівнем розвитку.

Значний внесок у реформування зокрема аграрного сектору України було здійснено Указом Президента України від 3 грудня 1999 р. «Про невідкладні заходи щодо прискорення реформування аграрного сектора економіки», що надало «можливості розширювати особисті підсобні господарства населення без створення юридичної особи за рахунок цих ділянок (земельного паю), а також одержаних при виході 3 зазначених підприємств майнових паїв» (Sabluka and Mesel-Veseliaka, 2000).

Господарства населення - це форма організації процесу виробництва на селі, яка змінювалась, вдосконалювалась, інтегрувалась в результаті розвитку економіки, проведених реформ, трансформації існуючих за часів Радянського Союзу колгоспів, радгоспів та міжгосподарських підприємств 3 метою створення нових форми господарювання. Кризова ситуація, яка супроводжувала аграрний сектор в період економічної кризи в Україні призвела до кардинальних змін в обсягах виробництва сільськогосподарської продукції, адже, якщо раніше основна частка виробництва припадала на сільськогосподарські підприємства та фермерські господарства, то в цей період саме господарства населення швидкими темпами нарощували обсяги виробництва. Тому важливо у науковому дослідженні зосередити увагу на особливостях їхнього розвитку.

Успіх інтенсивного розвитку господарств населення побудований на власній зацікавленості кожного селянина. Відомий науковець С.М. Злупко з цього приводу писав: «Якою є людина, такою є економіка». Професор М.Г. Шульський в своїй монографії стверджує, що «...якими особистими якостями характеризується сільський господар, таким рівнем розвитку відзначається його приватна господарка» (Shulskyi, 2003).

Ознакою «подвірні» виокремлювали господарства, які займаючи певну земельну площу, мали у розпорядженні двір, на якому розміщені будівлі, де могли утримуватись тварини. За часів існування колишнього Радянського Союзу господарства виокремлювали таку назву для господарств населення, як «підсобні», основною функцією яких було формування допоміжного джерела надходження продовольчих та фінансових засобів, необхідних для життя селян. При цьому основну роботу власники «підсобного господарства» повинні були виконувати у колгоспах, радгоспах - основних місцях праці. Враховуючи, що у колгоспах рівень оплати праці був на низькому рівні, члени колгоспів змушені були розвивати власні підсобні господарства і в ефективності їх роботи були зацікавлені більше, ніж в основній роботі на господарствах суспільного сектора. В практиці функціонування колгоспів було надання їх членами за відповідну кількість відпрацьованих років ділянки для обробітку (наділи), але вони були гірші за родючістю. Звідси і пішла ще одна назва таких господарств як «присадибні».

За останні десятиліття ці форми господарювання у своєму історичному розвитку пройшли різні етапи, що відображали необхідність жителів сільської місцевості за рахунок результативності свої праці задово- льняти власні потреби, та в кінцевому підсумку отримали назву господарства населення.

Враховуючи динамічність, випадковість та ймовірність виникнення господарських процесів у період реформування аграрного сектору, незважаючи на широку базу методів моделювання, прогнозування та економічної оцінки, виникає необхідність використання ширшого кола оцінок і прогнозів експертів практично у всіх напрямах дослідження ринкових тенденцій. Це зумовлює формування якісно нового рівня методичних підходів до підготовки й проведення економічних досліджень, що забезпечуватимуть стабільний розвиток та підвищить результативність використовуваних механізмів у змінних умовах ринкових відносин.

У результаті проведених реформ в сільському господарстві суб'єкти підприємництва відокремились в різні організаційні форми господарювання, за формою власності та складністю виробничих відносин. Для великого селянського (фермерського) господарства характерним є складність побудови взаємопов'язаних виробничих відносин порівняно із господарствами населення, оскільки додатково необхідно залучати земельні ресурси, допоміжних робітники щодо яких фермер застосовує управлінський вплив.

Остаточно функції управління чітко викристалізовуються при кооперативній формі господарювання, хоча і остаточно завершується процес їх формування при класичних формах ведення господарства. Такі форми господарювання уже володіють відповідними рисами, характерними для економічних систем: розподіл прав власності, поділ праці, чітке виокремлення функцій управління, i, як наслідок - висока ефективність виробництва, високий рівень товарності.

Варто відмітити виникнення особливих форми підприємницької діяльності, що побудовані на принципах вертикальної інтеграції, відповідно до яких передбачається наявність у конкретного виробника сільськогосподарської продукції певної частки на ринку. Такі форми ведення господарства на ринку $є$ найбільш пристосовані до змінних умов ринкової кон'юнктури, однак вимагають дещо іншого підходу. У таких формах простежується максимальне відділення відносин власності від виробничих відносин.

Прикладом спрощеного варіанту вертикальної інтеграції на регіональному рівні є діяльність агрофірм і міжгосподарських підприємств. Адже для того, щоб підприємство сільського господарства мало змогу нарощувати виробництво, чим забезпечити собі присутність на ринку, розширити межі впливу на ринку за рахунок виходу на інші сегменти, необхідні фінансові ресурси, обсяг яких інколи перевищує потенційні можливості окремих господарств. У таких умовах актуальним є використання міжгалузевої інтеграції, основою якої є об'єднання фінансових структур 3 перспективними підприємствами сільськогосподарського ринку або 3 іншими вертикально інтегрованими економічними суб'єктами (корпораціями) підприємницької діяльності, у власності яких наявні необхідні ресурси або володіння правами на їхнє використання. 
Використання виду інтеграції відіграє істотне значення при визначенні організаційної форми підприємницької діяльності. Застосування механізму холдингового типу доречне тоді, коли передбачається вторинна передача прав власності суб'єктами підприємницької діяльності на сформовані структури, що дозволить максимально полегшити формування як системи управління, так і зміну власників.

Наступним різновидом організаційної форми підприємницької діяльності у сільському господарстві є кооперація. Активізує процеси розвитку кооперації мотиваційний механізм, оскільки економічні відносини кожної форми господарської діяльності проявляються насамперед як результат діяльності. Реалізується мотиваційний механізм на основі принципів соціального партнерства, що передбачає узгодженість інтересів і дій партнерів з метою досягнення конструктивного результату. Кооперація, враховуючи специфіку іiі роботи, в найбільшій мірі вимагає дотримання принципу соціального партнерства від усіх іiі учасників, в іншому випадку це загрожуватиме втратою ринку, зниженням рівня прибутковості, невідповідністю прийняття рішень під впливом змінних умов зовнішнього середовища.

Проведення ринкових перетворень в сільському господарстві призвело до зміни власності та засобів виробництва, а також супроводжується високим рівнем приватизації землі. Академік П.Т. Саблук з цього приводу пише: «...перехід від повного одержавлення власності до різних іiі рівноправних форм є позитивним явищем, бо багаторічне нехтування приватною власністю не забезпечувало народному господарству України необхідного розвитку і вона з кожним роком відставала від інших високо розвинутих країн, які будують виробничі та економічні відносини на основі приватної власності. Як наслідок, у сільському господарстві, як і в більшості галузей народного господарства, продуктивність праці у роки найвищої підойми (1982-1985 рр.) було значно нижчою, ніж у передових зарубіжних країнах» (Sabluk, 1999).

На законодавчому рівні зміна прав власності закріплена в Законах України «Про господарські товариства», «Про форми власності на землю», «Про селянське (фермерське) господарство», «Про внесення змін до закону України «Про селянське (фермерське) господарство», у яких зазначено різновиди прав власності на землю, а саме державна, приватна та колективна. В результаті процесу паювання землі та майна виникають фермерські та селянські спілки, що працюють на засадах приватної та колективної форми господарювання. Власники паїв за своїм бажанням створюють власні фермерські господарства чи беруть участь у селянських спілках.

Господарства населення - це певний різновид підприємницької діяльності, заснований на приватній формі власності, що передбачає виробництво, споживання сільськогосподарської продукції та реалізацію іiі надлишків. Саме господарствах населення реалізують економічні інтереси жителів сільської місцевості в динамічному ринковому середовищі. Завдяки ефективній взаємодії та поєднанню економічних інтересів господарств населення та інших суб'єктів господарю- вання на ринку, зокрема і держави, визначено передумови для створюється середнього класу на селі.

Ринкові умови в Україні зумовили створення та розвиток фермерських господарств. Селянське фермерське господарство - це форма організації сільськогосподарського виробництва громадян на основі самостійного об'єднання жителів сільської місцевості, а напрямом його роботи є виробництво певних продуктів харчування та сировини з метою одержання прибутку. Фермерство як відносно нова форма підприємницької діяльності повинно зайняти певну нішу на ринку продовольства і сировини.

Проте вагоме місце у розвитку форм підприємницької діяльності належить підприємству, що створюється на основі залучення діяльністю громадян або об'єднання певної кількості фізичних осіб з метою виробництва продукції, іiї продажу, надання послуг для задоволення потреб споживачів, посередників, замовників і одержання відповідного рівня доходу. В певну групу доречно виділити сільськогосподарські підприємства.

Розвиток та функціонування сільськогосподарського підприємства забезпечує інтенсивний розвиток як агарного сектору економіки, так і сільського господарства зокрема. Адже підприємницька діяльність характеризується інтенсивним використанням новітніх технік та технологій в організації виробничого процесу. Це дозволяє нарощувати ефективність виробництва, пропонувати нові робочі місця, розширювати асортимент товарів та послуг, укріплюючи та розширюючи позиції на ринку. Характерною ознакою підприємницької діяльності $є$ мотиваційний інтерес власників, які активно працюють з метою збільшення свого прибутку, використовуючи при цьому різноманітні економічні стратегії.

Чітко сформована хороша та якісна стратегія надасть можливість суб'єкту підприємницької діяльності сільського господарства визначити та закріпити за собою місце на ринку, а іiі реалізація покладена на інструменти асортиментної, комунікаційної та збутової політики.

У сільському господарстві виділяють декілька типів підприємницьких стратегій, враховуючи вплив ринкових чинників макро- та мікросередовища. Перший тип побудований на використанні політичних інновацій, забезпечуючи тим самим більш конкурентоспроможне становище на ринку. Другий тип підприємницької стратегії побудований на поліпшенні якісних параметрів продукції. Третій вид підприємницької стратегії орієнтований на одержання монопольного становища певного ринку за рахунок найповнішого задоволення його потреб, отримуючи при цьому лідерство у конкурентній боротьбі. Четверта стратегія орієнтована на диференціацію цінової політики завдяки впровадженню інноваційних технологій у виробництво продукції, надавши тим самими ій відмінних властивостей. Це дозволить підприємству вести успішну конкурентну боротьбу на ринках збуту запропонованої ним продукції.

На думку вченого В. Ольховінова, формування стратегії розвитку сільськогосподарських форм підприємницької діяльності повинна включати певні напрями, а саме: 
- забезпечення угіддями - ключовий чинник, що дає змогу досягнення вищих результатів, адже підприємства 3 більшими земельними площами краще забезпечені капіталом, який є основою у формуванні матеріально-технічної бази;

- впровадження прибуткових видів діяльності, адже за належного рівня прибутку забезпечується стабільний розвиток підприємства, з'являється можливість модернізації виробництва та реформування господарської діяльності, формується кваліфікований кадровий склад як по горизонталі, так і по вертикалі;

- впровадження інноваційних технологій з урахуванням чинників виробництва та можливостей для їх придбання, методів управління для пошуку кращих рішень щодо зниження витрат виробництва та забезпечення конкурентоспроможності виготовленої продукції;

- врахування дії економічних законів щодо рівня приросту прибутку;

- використання праці найманих працівників на сезонні роботи, щоби зменшити навантаження на фонд оплати праці;

- збільшення частки ринку за рахунок активної маркетингової політики та покращення якості продукції, пропонованої на ринок;

- формування кадрової політики та підвищення кваліфікації працівників (Olkhovinov and Hrytsyshyn, 2005).

Питання власності у розвитку сільськогосподарського підприємства постає достатньо актуально. Тому серед сільськогосподарських підприємств виділяються державні, колективні та приватні. Державне сільськогосподарське підприємство - це підприємство, засноване на основі державної власності на засоби виробництва. Як юридична особа державне підприємство є суб'єктом майнових правовідносин. На ринку державні підприємства наділені певними правами.

Найбільша частка в структурі сільськогосподарського підприємництва за формою власності належить колективним та приватним. До колективних відносять: селянські спілки, агрофірми, виробничі, заготівельні та збутові кооперативи, товариства. Засновані колективні підприємства на основі колективної право власності. Для прикладу, виробничий кооператив - це організаційно правова форма підприємницької діяльності, яка здійснюється не менше, як трьома громадянинами, що на добровільних засадах об'єднали свої майнові, фінансові, трудові ресурси, а кінцевою метою їх діяльності є одержання належного рівня доходу. Учасники згадуваного кооперативу, окрім внесків своїх паїв в загальний статутний фонд, повинні бути залучені у весь трудовий процес кооперативу.

Різновидом колективної форми власності підприємницької діяльності є товариство. В Україні даний різновид форми підприємницької діяльності $€$ найбільш поширеним в економіці та у сільському господарстві зокрема. Створюються господарські товариства на основі укладання угоди між кількома особами, які для здійснення підприємницької діяльності надають у розпоряджання товариства своє майно і капітал. Кожен $з$ них відповідає за організацію виробництва, розподіляючи при цьому рівномірно ризик, прибутки та збитки.

За формою об'єднання та рівнем відповідальності товариства можна поділити на товариства з обмеженою відповідальністю, з повною, додатковою відповідальністю, а також командитні та акціонерні товариства (Maiona, 2001).

Командитне товариство - це товариство, побудоване на засадах, коли поряд з одним або більшістю учасників, які несуть відповідальність за зобов’язаннями товариства всім своїм майном, існує також один або більше учасників у такому товаристві, відповідальність яких обмежується внеском у майно товариства. Тобто у командитних товариства поряд $з$ учасниками, які несуть відповідальність всім своїм майном, включаються і учасники, що відповідають лише своїми вкладами.

Акціонерне товариство - це товариство, статутний фонд якого формується на основі визначеної кількості акцій, що є рівної вартості, а власники цих акцій несуть відповідальність лише майном товариства. Ринкові умови створюють сприятливі можливості для розвитку акціонерних товариств, оскільки будь-яке об'єднання підприємств і організацій, що входять у його структуру як самостійні юридичні особи за умов укладання договору між ними може стати акціонерним товариством.

Виділяють два види акціонерних товариств:

- публічне акціонерне товариство - це товариство, акції якого розповсюджуються шляхом відкритої купівлі-продажу на біржах;

- приватне акціонерне товариство - це товариство, акції якого розповсюджуються тільки між засновниками цього товариства і не можуть продаватися на біржах.

Результати дослідження свідчать, що найчастіше за організаційно- правовою формою зустрічаються на ринку товариства 3 обмеженою відповідальністю (ТзОВ). Вони становлять найбільшу частку в структурі серед всіх видів товариств. На відміну від акціонерного товариства учасники ТзОВ спільно здійснюють підприємницьку діяльність, проте несуть матеріальну відповідальність лише своїм майном.

За умови, коли учасники здійснюють спільну підприємницьку діяльність, а рівень відповідальності за взяті зобов'язання носить спільний характер - ця організаційно-правова форма відповідає принципам повного товариства.

Для товариства 3 додатковою відповідальністю характерним є додатковий рівень відповідальність його учасників, оскільки відповідають вони не лише своїми вчинками, а й частково власним майном.

Об'єднання виробників сільськогосподарської продукції існують в багатьох країнах світу, зокрема i в Свропейському Союзі.

Основними вигодами такої консолідації сільськогосподарських виробників є:

- підтримка зі сторони ЄС для таких груп;

- спільна закупівля засобів виробництва (можливість користати 3 оптових цін, цінових знижок, кращих умов оплати); 
- сильніша маркетингова діяльність та можливість комунікації зі споживачами;

- можливості застосування сучасних технологій виробництва та інтенсифікація біологічного прогресу (обмін насінним матеріалом, використання кращих порід і сортів тощо);

- спільна закупівля машин і обладнань, спільне використання бази зберігання і складування;

- зниження витрат на постачання засобів виробництва і збут сільськогосподарської продукції шляхом ефективної транспортної логістики;

- економія часу завдяки гуртовому постачанню i продажу;

- якісна і сортова уніфікація партії товарів і ї продаж гуртовим клієнтам, відповідно можливість досягнення відповідної ціни);

- створення власної мережі кліснтів (гуртові, переробні підприємства, заклади торгівлі та громадського харчування) (Smolynets, 2014).

Сучасні тенденції суспільних перетворень не обмежуються певними соціальними, економічними або техніко-технологічними процесами, а полягають в їх надзвичайно складному поєднанні, що вимагає узгодження, часто різнорідних суспільних вимог і потреб шляхом якісної переорієнтації пріоритетів управління на інноваційний розвиток. Аграрний сектор економіки України як складна відкрита система розвивається відповідно до загальних економічних закономірностей, а наслідки господарської діяльності корегуються до різних параметрів зовнішнього і внутрішнього характеру (Smolynets, 2012).

Вимоги ринкової економіки формують правила щодо розвитку видів форм підприємницької діяльності у сільському господарстві. Кожна з цих форм базується на певних принципах та методичних підходах. Проте варто зазначити, що розвиток форм підприєм- ницької діяльності в сільському господарстві поки що не $\epsilon$ на завершальному етапі, завдяки ефективній інвестиційній політиці можливі інноваційні підходи до їхнього формування. Лише завдяки потужним інструментам їх розвитку можна радикально підвищити рівень ефективності як аграрного сектору економіки, так і сільського господарства зокрема.

Незважаючи на те, що господарства населення $є$ найчисельнішою організаційно-правовою формою підприємницької діяльності в сільському господарстві Львівської області, які виготовляють 70\% від обсягу валової продукції сільського господарства, їхня питома вага у структурі формуванні валового виробництва сільської продукції перебуває на низькому рівні. Для порівняння наведемо характеристику сильних і слабких сторін основних організаційно-правових форм підприємницької діяльності в сільському господарстві Львівської області (табл. 1).

Дослідження дають змогу стверджувати, що здійснювати економічну оцінку ефективності виробництва в різних формах підприємницької діяльності сільського господарства необхідно з ураховуванням таких чинників, як рівень концентрації виробництва, форма власності на засоби виробництва й спосіб ії використання. При цьому очевидно, що не існує єдиного універсального підходу до вибору показників оцінки ефективності організаційно-правової форми підприємницької діяльності, тому й неможливо запропонувати оптимальну форму підприємницької діяльності для різних природно-кліматичних умов. Звичайно, проводити оцінку ефективності функціонування різних організаційно-правових форм підприємницької діяльності, варто, використовуючи не лише універсальні методичні підходи, а й враховуючи конкретні відповідні умов їх роботи.

Характеристика сильних і слабких сторін основних організаційно-правових форм підприсмницької діяльності в сільському господарстві Львівської області *

\begin{tabular}{|c|c|c|c|}
\hline Ознака & Господарства населення & Аграрні підприємства & Фермерські господарства \\
\hline $\begin{array}{l}\text { Сильні } \\
\text { сторони }\end{array}$ & $\begin{array}{l}\text { - високий рівень соціальної } \\
\text { ефективності; } \\
\text { - великий обсяг робочих місць; }\end{array}$ & $\begin{array}{l}\text { - спеціалізація виробництва; } \\
\text { - ширина процесу виробництва; }\end{array}$ & $\begin{array}{l}\text { - плюси невеликих підприємств; } \\
\text {-незначні трансакційні витрати; }\end{array}$ \\
\hline $\begin{array}{l}\text { Слабкі } \\
\text { сторони }\end{array}$ & $\begin{array}{l}\text { - низький рівень продуктивності } \\
\text { праці; } \\
\text { - важкість в опануванні новітніх } \\
\text { технологій; }\end{array}$ & $\begin{array}{l}\text {-значні обсяги трансакційних } \\
\text { витрат; } \\
\text {-слабо продуманий мотиваційний } \\
\text { механізм; }\end{array}$ & $\begin{array}{l}\text { - недостатній рівень інвестицій- } \\
\text { них ресурсів; } \\
\text {-наявність перешкод у розвитку } \\
\text { тваринництва; }\end{array}$ \\
\hline $\begin{array}{l}\text { Потенційні } \\
\text { можливості }\end{array}$ & $\begin{array}{l}\text { - розвиток виробництва екологічно } \\
\text { чистої продукції; } \\
\text { - виробництво «під індивідуальне } \\
\text { замовлення» }\end{array}$ & $\begin{array}{l}\text {-коригування величини витрат на } \\
\text { виробництво продукції; } \\
\text {-зростання рівня конкуренто- } \\
\text { спромож-ності продукції; }\end{array}$ & $\begin{array}{l}\text {-можливість швидкого пристосу- } \\
\text { вання до умов кон’юнктури } \\
\text { ринку; } \\
\text {-компактність виробництва; }\end{array}$ \\
\hline $\begin{array}{l}\text { Загрози } \\
\text { (у перспек- } \\
\text { тиві) }\end{array}$ & $\begin{array}{l}\text { - невідповідність асортиментної } \\
\text { політики вимогам ринку; } \\
\text { - зниження рівня конкуренто- } \\
\text { спроможності; }\end{array}$ & $\begin{array}{l}\text { - зміна ринкових умов функціо- } \\
\text { нування після вступу до СОТ; } \\
\text { - диференціація цін; }\end{array}$ & $\begin{array}{l}\text { - економічний тиск з боку вели- } \\
\text { ких підприємств; } \\
\text { - значна залежність від кредит- } \\
\text { них ресурсів; }\end{array}$ \\
\hline
\end{tabular}

*Власні напрацювання автора

Формування та розвиток структури сільськогосподарського виробництва, форм підприємницької діяльності здійснювалось під впливом політичних, соціальних, економічних процесів, які супроводжували становлення незалежної держави. Саме зміна соціально-економічних умов розвитку країни призвела до потреби вдосконалення виробничої структури сільського господарства, пошуку механізмів побудови сільськогосподарського підприємництва, що гарантуватиме належний рівень її продовольчої безпеки. 


\section{Висновки}

1. Організаційно-правова форма підприємницької діяльності в сільському господарстві - це економічно відокремлений і господарсько-самостійний, юридично визнаний вид організації виробничої діяльності, що характеризується змістом використання певної форми власності та відповідними економічними взаємовідносинами, способами здійснення аграрного виробництва та структурою.

2. В аспекті розвитку підприємницька діяльність має такі форми: приватні підсобні господарства, одноосібні володіння, господарства населення, селянські фермерські господарства, приватні та державні сільськогосподарські підприємства, колективні господарства, зокрема селянські спілки, агрофірми, міжгосподарські підприємства і об'єднання, різного роду та видів товариства, які поділяються за формою об'єднання та рівнем відповідальності. Найважливіші 3 них, які прижились та функціонують в сільському господарстві, $є$ сільськогосподарські підприємства, зокрема приватні, та господарства населення.

3. Сільськогосподарське підприємство забезпечує функціонування агропромислового комплексу та його інтенсивний розвиток, тому що саме підприємницька діяльність характеризується новітнім використанням технологій та організацією управління виробництвом. У результаті цього зростає ефективність виробництва, збільшується зайнятість населення, створюються нові товари і послуги, розширюється ринок. Однією з основних ознак підприємницької діяльності є приватний інтерес.

4. Розвиненою моделлю підприємницької діяльності в США та в європейських країнах є фермерство, де на фермах, навіть на великих, застосовується праця переважно членів родини. Іншою особливістю американської моделі підприємницької діяльності $є$ те, що на фермах застосовується продуктивна сільськогосподарська техніка і комп'ютерне забезпечення виробничої діяльності. Важливим чинником розвитку американського фермерства $€$ тісна співпраця фермерів 3 науковцями та застосування останніх наукових розробок на практиці. Це сприяє підвищенню продуктивності праці, ефективності господарювання та доходності фермерів.

Перевагами фермерської моделі підприємницької діяльності є з одного боку наявність господаря, а 3 іншого - усунення такого негативного явища у вітчизняному сільському господарстві, як концентрація великих масивів сільськогосподарських угідь в господарстві однієї особи або підприємства.

\section{Бібліографічні посилання}

Berezivskyi, P.S. (2006). Ahrarna polityka $v$ umovakh rynkovoi transformatsii ekonomiky ahropromyslovoho kompleksu: kol. Monohrafiia. Lviv: LDAU (in Ukrainian).

Haidutskyi, P.I. (2005). Ahrarna reforma v Ukraini. K.: NNTs IAE (in Ukrainian).

Hladiy, M. (1994). Ahrarna reforma na Lvivshchyni: Dokumenty i materialy (1990-1994). Lviv: Kameniar (in Ukrainian).

Yanchuk, V.Z. (2000). Ahrarne pravo Ukrainy. K.: Yurinkom Inter (in Ukrainian).

Maiona, P.O. (2001). Ekonomika i orhanizatsiia ahrarnoho servisu (in Ukrainian).

Kostetska, Ya. (1996). Do istorii zemelnykh vidnosyn ta zemelnykh reform v Ukraini. Vilnyi ahrarnyk. 1, 142 (in Ukrainian).

Sabluka, P.T., Mesel-Veseliaka, V.Ya. (2000). Posibnyk z reformuvannia silskohospodarskykh ta pererobnykh pidpryiemstv. IAE UAAN. K. (in Ukrainian).

Olkhovinov, O.V., Hrytsyshyn, O.B. (2005). Osnovy ekonomiky ahropromyslovoho vyrobnytstva. K., 1112 (in Ukrainian).

Sabluk, P.T. (1999). Rozvytok hospodarskykh formuvan i orhanizatsiia vyrobnytstva $\mathrm{v}$ ahrarnii sferi APK. K.: IAE (in Ukrainian).

Sait Yevropeiskoho komitetu statystyky. [Elektronnyi resurs]. Yevropeiskyi komitet statystyky. - Elektronni dani. - Liuksemburh: Yevropeiska komisiia, 2013 (in Ukrainian).

Smolynets, I.B. (2014). Perspektyvy rozvytku riznykh orhanizatsiinykh form pidpryiemnytskoi diialnosti $\mathrm{v}$ silskomu hospodarstvi. Zbirnyk materialiv III Mizhnarodnoi naukovo-praktychnoi konferentsii Lvivskoho natsionalnoho universytetu imeni Ivana Franka, 288-290 (in Ukrainian).

Smolynets, I.B. (2012). Indeksnyi analiz diialnosti ahrarnykh formuvan Lvivskoi oblasti u konteksti konkurentospromozhnosti. Zbirnyk naukovykh prats Khmelnytskoho universytetu upravlinnia ta prava. Khmelnytskyi, 128-134 (in Ukrainian).

Shulskyi, M.H. (2003). Osobysti hospodarstva naselennia: stan, mozhlyvosti i perspektyvy. Monohrafiia. Lviv: [vyd-vo «Krai»] (in Ukrainian).

Стаття надійшла до редакиії 13.03.2017 